SEX DETERMINATION OF DATE PALM (PHOENIX DACTYLIFERA L.) THROUGH CHEMICAL COMPOSITION OF LEAVES

\author{
Mohamed A. Seif El-Yazal
}

Dep. of Agric. Botany, Fac. of Agric. Fayoum, Univ., Egypt.

\begin{abstract}
This investigation was carried out during the two successive seasons of 2006 and 2007 using 8 years old date palm trees of Seewy" cultivar grown in clay soil located at Sinnaouris Fayoum Governorate, Egypt. The objective of this study was to predict sex of date palm through some leaf chemical constituents. Generally, it was found that there are great differences in chemical constituents of pinnae, i.e. chlorophyll a \& b, total caroteniods, total anthocyanin, total carbohydrates, total and reducing sugars, total free amino acids, free proline, total indoles, nitrogen, crude protein, total phenols, dry matter, ash and silicon between male and female date palm (c.v. Seewy"). Female trees were characterized by the increase in the concentration of chlorophyll a \& b, total caroteniods, total anthocyanin, total carbohydrates, total and reducing sugars, total free amino acids, total indoles, nitrogen, crude protein, total phenols, dry matter and silicon over male trees. On the contrary, male trees were characterized by the increase in the concentration of ash and proline over female trees.

From the obtained results, it has been concluded that female date palm plants was characterized by high capacity to anabolism and the accumulation of these substances resulting from these processes and vice versa in pinnae of male date palm plants. These pinnae chemical analysis can be used as a mean for predicting sex in date palm plant "Seewy" cultivar.
\end{abstract}

Key Words: Date palm (Phoenix dactylifera L.), sex determination, pinnae chemical constituents.

\title{
INTRODUCTION
}

Date palm (Phoenix dactylifera L.) in one of the leading fruit crops all over Egypt. The date palms can grow under different conditions, where many other fruit species fail to grow. For this reason it is most suitable for cultivation in the newly reclaimed desert area, especially in sandy soils (Ashour et al., 2004). "Seewy" date palm cultivar is classified as one of the leading semi-dry date cultivars in Egypt, especially in Fayoum Governorate where it is considered as the most common cultivar widely grown in such Governorate (Mohammed, 2004). Many investigators studied the effect of pollens obtained from different palm males cultivar and "Seewy" male palm cultivar on fruit set, yield and fruit physical and chemical properties (fruit weight, flesh weight, fruit length and diameter, T.S.S. and tannins content) of several female palm cultivars (El-Makhtoun, 1979; Khalifa et al., 1980; Higazy et al., 1982a and b; El- Ghayaty, 1982; Moustafa, 2001 and Abd El-Rawy, 2001). In this respect Abd El-Rawy (2001) found that the fruit set percentage varied according to the type of pollinator. "Seewy" cv. was higher in their fruit set percentage in comparison to other cultivars. The fruit set was (45.87, 53.38, 65.35, 67.31, 70.12 and 75.14\%) in "Zaghloul, Samany, Amry, Halawy, Haiany and Seewy", respectively. Moreover, it is well recognized that

Fayoum J. Agric. Res. \& Dev., Vol.22, No.2, July, 2008 
date palm is a dioecious plant, i.e. male and female flowers are borne on separate plants. Natural pollination may occur by wind and insects. If the pollination process is dependent on these two methods, the palm cropping will be shy and the fruits may be of inferior quality due to inadequate pollination. Therefore, artificial hand pollination becomes a necessity as a mean to ensure good yield. On the other hand, date palm is a dioecious plant and one male is sufficient to ensure perfect pollination for twenty female palms. Thereupon, the growth and development of offsets into male palms, which are detected only at fruiting stage (after seven years from planted) are considered not only useless plants, but also a great loss from the commercial point of view. Consequently the determination of sex in date palm in early stage of growth is very important from the commercial point of view. Little investigators studied the differences between male and female date palms (Phoenix dactylifera L.) trees i.e. Bahgat and Brown (1958) on date palms cv. Samany and Zaghloul. On the other hand, several investigators studied the differences between male and female papaya (Carica papaya L.) trees i.e. Khan et al. (1982); Dutta and Mazumdar (1989); Helail and Atawia (1990) and Salama (1998) using the chemical analysis of leaves.

Accordingly, the present investigation was carried out to predect sex of date palm through detecting the relationship between some leaf chemical constituents and sex expression of date palm trees during 2006 and 2007 seasons by the aim to separate the male offsets from female ones early in nursery before cultivation in permanent orchard, where about $50 \%$ from offsets come from seeds were male offsets.

\section{MATERAL AND METHODS}

The present investigation was conducted during two successive seasons 2006 and 2007 on date palm trees of "Seewy" cultivar grown in clay soil located at Sinnaouris, Fayoum Governorate, Egypt. The objective was to get some information about the relationship between sex expression of "Seewy" date palm and some leaf chemical constituents. The experimental palms were healthy, as they were uniform in growth, vigour and height and received all cultural practices according to the traditional schedule for experimental palms. The presented experiment contained 20 trees of both female and male date palm. The trees were eight year old, newly emerged leaf was selected from each palm, samples consists of five leaves from each tree and from each leaf ten pinnae were taken by detaching five pinnae from each side of the mid-portion rachis of male and female leaves. Leaflets samples were taken during November of both seasons and washed with tap water and then with distilled water to remove the dust and any chemical spray residues. After washing, samples were used fresh or dry (the samples were dried in an electric over at $70 \mathrm{C}^{0} \pm 2$ till constant weight, then finely ground)

\section{Chemical constituents:}

Numbers of the following chemical constituents were determined in fresh pinnae and the other in the powdered dry pinnae.

1- Photosynthetic pigments:

The photosynthetic pigments (chlorophyll $\mathrm{a} \& \mathrm{~b}$ as well as total caroteniods) were extracted by homogenizing $0.5 \mathrm{gm}$ fresh pinnaes in $100 \mathrm{ml}$ $80 \%$ acetone, with the addition of traces of $\mathrm{MgCO}_{3}$. The absorbance of the clear extract was measured at 663, 646 and 470nm. The concentration of chlorophyll $\mathrm{a} \& \mathrm{~b}$ as well as total caroteniods were calculated as $\mathrm{mg} / 100 \mathrm{~g}$ fresh weight according to the formulae of Welburn and Lichtenthaler (1984).

Fayoum J. Agric. Res. \& Dev., Vol.22, No.2, July, 2008 
SEX DETERMINATION OF DATE PALM (PHOENIX DACTYLIFERA L .78

$\mathrm{Chl} \mathrm{a}=12.21 \mathrm{E}_{663}-2.81 \mathrm{E}_{646}$

$\mathrm{Chl} b=20.13 \mathrm{E}_{646}-5.03 \mathrm{E}_{663}$

$\mu \mathrm{g} \mathrm{ml} \mathrm{m}^{-1}$

Carotenoids $=\frac{1000 \mathrm{E} 470-3.27 \mathrm{Chl} \mathrm{a}-104 \mathrm{Chl} \mathrm{b}}{229} \mu \mathrm{g} \mathrm{ml}^{-1}$

2- Total anthocyanin

Total anthocyanin was extracted by homogenization of 1.0 gram from grounded dried pinnaes in 95\% ethanol and $\mathrm{HCl} 1.5 \mathrm{~N}(85: 15 \mathrm{v} / \mathrm{v})$ and filtered using vacum pump. The absorbance of the extracted solution was measured at $535 \mathrm{~nm}$. The concentration of total anthocyanin was calculated as $\mathrm{mg} / 100 \mathrm{~g}$ dry weight according to the formulae of Fuleki and Francis (1968).

Total anthocyanin $\mathrm{mg} / 100 \mathrm{~g} .=$ O.D. $.535 \times$ D. $\mathrm{V} \times 100 / \mathrm{P} . \mathrm{W} \times 1 / 98.2$

Where O.D. = The optical density of the diluted sample.

D.V. = Diluted volume as the volume in $(\mathrm{ml})$ of the diluted extract prepared for the O.D. measurement.

P.W. = pinnae weight in grams

3- Total carbohydrates $\mathrm{g} / 100 \mathrm{~g}$ dry weight was extracted by sulphuric acid $(0.1$

$\mathrm{N})$ then determined colorimetrically by using phenol-sulphuric acid reagent according to the method described by Michel $\boldsymbol{e t}$ al. (1956).

4- Total and reducing sugars were determined in ethanolic extract using phosphomolybdic acid reagent as described by A.O.A.C. (1995), and calculated as $\mathrm{g} / 100 \mathrm{~g}$ dry weight.

5- Total free amino acids in fresh pinnae were determined colorimetrically in ethanolic extract using ninhydrin reagent according to the method described by Jayarman (1981) and calculated as $\mathrm{mg} / \mathrm{g}$ dry weight.

6- Free proline concentration ( $\mathrm{mg} / \mathrm{g}$ dry weight) was extracted by sulfosalicylic acid (3\%) then, determined colorimetrically at $535 \mathrm{~nm}$ using acid ninhydrin and toluene reagent as outlined by Bates et al., (1973).

7- Total indoles $\mathrm{mg} / \mathrm{g}$ fresh weight were determined in ethanolic extract using 4-dimethylaminobenzaldehyde reagent as described by Larson $\boldsymbol{e t}$ al. (1962).

8- Total phenols in fresh pinnae were determined in ethanolic extract using Folin-Denis reagent as described by A.O.A.C. (1995) and calculated as $\mathrm{mg} / \mathrm{g}$ fresh weight.

9- Nitrogen $\%$ in pinnae was determined, using the Orange $\mathrm{G}$ dye colorimetric method (Hafez and Mikkelsen, 1981).

10 - Crude protein was calculated by nitrogen $\% \times 5.75$.

11- Dry matter of male and female pinnae was determined according to A.O.A.C. (1995) and expressed as percentage.

12- Ash and silicon of male and female pinnae were determined according to Hanna's Method (1964) and expressed as percentage on dry weight basis.

Statistical analysis:

All the obtained data were subjected to analysis of variance according to

Snedecor and Cochran (1980). The differences between means were differentiated by using students t-test.

RESULTS

Chemical constituents:-

1- Leaf pigments:

a-Plastid pigment concentration

Data recorded in Tables ( 1 and 2$)$ clearly show that in both seasons, pinnae of female trees showed higher values of plastid pigments as compared with those of male trees in the two successive seasons. The increments

Fayoum J. Agric. Res. \& Dev., Vol.22, No.2, July, 2008 
reached about 19.58and $8.06 \%$ for chlorophyll a ; 23.29 and $20.09 \%$ for chlorophyll b, 54.00 and $58.02 \%$ for total caroteniods over the male trees respectively in the two successive seasons. Thus, it could be concluded that pinnae of plastid pigments could be used as a good parameter in predicting sex in date palm trees.

\section{b- Cell-sap pigment:-}

The results obtained in Table (2) indicate in both seasons that, pinnae of female trees recoded higher values of total anthocyanin in comparison with male trees. The increase was recorded 37.10 and $40.61 \%$ over the male trees in the first and second seasons, respectively.

On the other hand you can simply differentiate between the male and female date palm trees by the colour of ethanolic extract of pinnae sample which had orange coloure for female date palm and yellow green for male date palm

Table (1): Chlorophyll a and b concentration of male and female pinnae date palm in 2006 and 2007 seasons.

\begin{tabular}{|c|c|c|c|c|c|c|c|c|}
\hline \multirow{3}{*}{$\begin{array}{c}\text { Trees } \\
\text { No. } \\
\end{array}$} & \multicolumn{4}{|c|}{ Chloroplyll a (mg/100 g F.W.) } & \multicolumn{4}{|c|}{ Chlorophyll b (mg/100 g F.W.) } \\
\hline & \multicolumn{2}{|c|}{2006} & \multicolumn{2}{|c|}{2007} & \multicolumn{2}{|c|}{2006} & \multicolumn{2}{|c|}{2007} \\
\hline & Male & Female & Male & Female & Male & Female & Male & Female \\
\hline 1 & 65.71 & 77.96 & 73.32 & 79.60 & 44.06 & 49.03 & 43.61 & 52.20 \\
\hline 2 & 60.33 & 79.15 & 70.15 & 76.11 & 40.60 & 51.63 & 43.10 & 55.50 \\
\hline 3 & 61.25 & 78.16 & 66.18 & 79.90 & 41.11 & 46.18 & 44.18 & 51.20 \\
\hline 4 & 63.65 & 75.15 & 72.10 & 73.33 & 39.71 & 54.61 & 42.15 & 51.23 \\
\hline 5 & 63.01 & 71.90 & 69.25 & 70.60 & 38.18 & 48.16 & 40.16 & 53.26 \\
\hline 6 & 64.10 & 75.55 & 66.99 & 69.18 & 39.90 & 50.50 & 43.25 & 46.33 \\
\hline 7 & 65.13 & 76.60 & 68.11 & 69.96 & 43.29 & 52.50 & 40.10 & 50.23 \\
\hline 8 & 61.66 & 73.18 & 67.15 & 76.11 & 40.55 & 53.18 & 44.44 & 48.21 \\
\hline 9 & 63.18 & 75.10 & 69.25 & 79.18 & 42.18 & 49.11 & 45.21 & 54.33 \\
\hline 10 & 64.10 & 73.21 & 72.11 & 76.66 & 40.36 & 50.50 & 43.26 & 53.21 \\
\hline Mean & 63.21 & 75.59 & 69.46 & 75.06 & 40.99 & 50.54 & 42.94 & 51.57 \\
\hline Sig.5\% & & & & & & & & \\
\hline
\end{tabular}

\section{2- Carbohydrates and Sugars concentration:-}

Data recorded in Tables (3and 4) clearly show that, total carbohydrates, total sugars and reducing sugars concentration were significantly higher in female trees than in male once. The increase recorded 15.48 and $15.50 \%$ for total carbohydrates; 21.94 and $20.36 \%$ for total sugars and 47.5 and $35.71 \%$ for reducing sugars over the male trees respectively in the two successive season .The obtained results in this study showed clearly that carbohydrates could be used safely to predict sex in date palm trees. 
SEX DETERMINATION OF DATE PALM (PHOENIX DACTYLIFERA L .80

Table (2): Male and female date palm pinnae concentration from total caroteniods and total anthocyanin in 2006 and 2007 seasons .

\begin{tabular}{|c|c|c|c|c|c|c|c|c|}
\hline \multirow{3}{*}{\begin{tabular}{|c|} 
Trees \\
No.
\end{tabular}} & \multicolumn{4}{|c|}{ Total carotenoids(mg/100 g F.W.) } & \multicolumn{4}{|c|}{ Total anthocyanin (mg/100 gD.W.) } \\
\hline & \multicolumn{2}{|c|}{2006} & \multicolumn{2}{|c|}{2007} & \multicolumn{2}{|c|}{2006} & \multicolumn{2}{|c|}{2007} \\
\hline & Male & Female & Male & Female & Male & Female & Male & Female \\
\hline 1 & 9.64 & 16.10 & 9.13 & 15.10 & 23.42 & 32.59 & 26.20 & 36.10 \\
\hline 2 & 9.10 & 16.32 & 9.86 & 16.16 & 24.15 & 36.60 & 26.81 & 33.15 \\
\hline 3 & 10.21 & 14.21 & 9.23 & 15.91 & 22.10 & 35.11 & 27.15 & 37.25 \\
\hline 4 & 11.0 & 15.25 & 10.23 & 14.12 & 23.61 & 32.16 & 25.26 & 36.60 \\
\hline 5 & 10.01 & 16.66 & 11.60 & 16.91 & 26.10 & 36.10 & 22.18 & 34.34 \\
\hline 6 & 9.80 & 15.20 & 10.33 & 16.00 & 23.11 & 33.15 & 27.27 & 37.21 \\
\hline 7 & 9.15 & 14.12 & 10.61 & 14.91 & 26.18 & 35.21 & 22.69 & 31.60 \\
\hline 8 & 9.76 & 15.25 & 10.91 & 16.18 & 24.50 & 30.30 & 26.18 & 36.22 \\
\hline 9 & 10.15 & 15.56 & 9.23 & 16.00 & 27.15 & 36.90 & 23.21 & 35.11 \\
\hline 10 & 11.01 & 15.10 & 9.19 & 17.27 & 27.90 & 32.21 & 23.00 & 33.90 \\
\hline Mean & 9.98 & 15.37 & 10.03 & 15.85 & 24.82 & 34.03 & 24.99 & 35.14 \\
\hline Sig.5\% & & & & & & & & \\
\hline
\end{tabular}

Table (3): Male and female date palm pinnae concentration from total carbohydrates and total sugars in 2006 and 2007 seasons .

\begin{tabular}{|c|c|c|c|c|c|c|c|c|}
\hline \multirow{3}{*}{$\begin{array}{c}\text { Trees } \\
\text { No. }\end{array}$} & \multicolumn{4}{|c|}{$\begin{array}{c}\text { Total carbohydrates }(\mathrm{g} / 100 \\
\text { gD.W.) }\end{array}$} & \multicolumn{4}{|c|}{ Total sugars (g/100 gD.W.) } \\
\hline & \multicolumn{2}{|c|}{2006} & \multicolumn{2}{|c|}{2007} & \multicolumn{2}{|c|}{2006} & \multicolumn{2}{|c|}{2007} \\
\hline & Male & Female & Male & Female & Male & Female & Male & Female \\
\hline 1 & 15.63 & 17.61 & 15.11 & 18.01 & 7.05 & 8.06 & 7.41 & 7.59 \\
\hline 2 & 14.90 & 18.20 & 16.10 & 17.11 & 6.33 & 8.25 & 7.20 & 8.60 \\
\hline 3 & 15.60 & 18.36 & 14.96 & 17.91 & 5.95 & 8.26 & 6.60 & 8.10 \\
\hline 4 & 16.61 & 17.35 & 15.10 & 18.10 & 7.10 & 7.90 & 5.81 & 8.36 \\
\hline 5 & 15.64 & 17.61 & 16.03 & 18.00 & 6.60 & 8.15 & 7.10 & 7.90 \\
\hline 6 & 14.93 & 17.83 & 16.60 & 18.55 & 6.53 & 8.30 & 6.90 & 8.06 \\
\hline 7 & 15.25 & 18.06 & 14.81 & 17.18 & 7.01 & 7.85 & 5.53 & 7.51 \\
\hline 8 & 14.01 & 17.17 & 15.33 & 18.32 & 6.60 & 8.80 & 7.15 & 7.60 \\
\hline 9 & 16.10 & 18.61 & 14.61 & 16.90 & 7.11 & 8.01 & 6.53 & 7.55 \\
\hline 10 & 15.66 & 17.41 & 14.90 & 17.25 & 6.77 & 8.18 & 6.15 & 8.60 \\
\hline Mean & 15.43 & 17.82 & 15.35 & 17.73 & 6.70 & 8.17 & 6.63 & $7 . .98$ \\
\hline Sig.5\% & \multicolumn{2}{|r|}{17.02} & \multicolumn{2}{|r|}{ 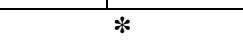 } & \multicolumn{2}{|c|}{$*$} & \multicolumn{2}{|c|}{$*$} \\
\hline
\end{tabular}

3-Dry matter accumulation (\%):

Data recorded in Table (4) show in both seasons that, there is a clear relationship between accumulation (\%) dry matter and sex expression of date palm trees. The highest accumulation $(\%)$ from dry matter were obtained with the female pinnae trees. The increase over the male trees was recorded 12.22 and $13.03 \%$ for dry matter accumulation (\%), respectively in the two successive seasons. 
Table (4): Male and female date palm pinnae concentration from reducing sugars and dry matter in 2006 and 2007 seasons.

\begin{tabular}{|c|c|c|c|c|c|c|c|c|}
\hline \multirow{3}{*}{$\begin{array}{c}\text { Trees } \\
\text { No. }\end{array}$} & \multicolumn{4}{|c|}{ Reducing sugars (g/100 gD.W.) } & \multicolumn{4}{|c|}{ Dry matter \% } \\
\hline & \multicolumn{2}{|c|}{2006} & \multicolumn{2}{|c|}{2007} & \multicolumn{2}{|c|}{2006} & \multicolumn{2}{|c|}{2007} \\
\hline & Male & Female & Male & Female & Male & Female & Male & Female \\
\hline 1 & 0.82 & 1.13 & 0.77 & 1.02 & 37.70 & 39.70 & 35.11 & 42.18 \\
\hline 2 & 0.80 & 1.15 & 0.91 & 1.25 & 35.10 & 41.15 & 37.12 & 40.40 \\
\hline 3 & 0.75 & 1.06 & 0.80 & 1.30 & 36.80 & 39.90 & 37.20 & 42.33 \\
\hline 4 & 0.93 & 1.25 & 0.75 & 1.01 & 37.76 & 41.15 & 37.10 & 43.25 \\
\hline 5 & 0.85 & 1.30 & 0.73 & 1.12 & 36.60 & 42.18 & 38.01 & 40.10 \\
\hline 6 & 0.81 & 1.25 & 0.79 & 1.07 & 35.50 & 41.25 & 37.11 & 42.18 \\
\hline 7 & 0.75 & 1.15 & 0.90 & 1.23 & 36.60 & 43.55 & 37.22 & 41.11 \\
\hline 8 & 0.73 & 1.10 & 0.89 & 1.30 & 35.56 & 39.83 & 37.10 & 42.15 \\
\hline 9 & 0.75 & 1.20 & 0.93 & 1.01 & 37.18 & 39.60 & 36.66 & 43.33 \\
\hline 10 & 0.81 & 1.30 & 0.94 & 1.11 & 35.12 & 40.10 & 37.21 & 41.01 \\
\hline Mean & 0.80 & 1.18 & 0.84 & 1.14 & 36.39 & 40.84 & 36.98 & 41.80 \\
\hline Sig.5\% & & 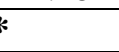 & & 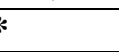 & & & & 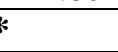 \\
\hline
\end{tabular}

\section{4- Silicon concentration:}

Data recorded in Table (5) show that, in both seasons there is a relationship between pinnae concentration from silicon and sex expression of date palm trees. The highest concentration of pinnae from silicon was obtained with the female trees. The increase over the male trees was recorded 70.94 and $73.46 \%$ for silicon concentration respectively in the two studied seasons. The obtained results in this study showed clearly that silicon could be used as a guide in forecasting the sex of date palm trees. The obtained results go in line with the findings reported earlier by Bahgat and Brown (1958) who mentioned that leaves of some female palms cv. Samany and Zaghloul contain higher silicon \% than those of male ones.

\section{5- Total soluble phenols concentration:-}

Data recorded in Table (5) clearly show that total soluble phenols of pinnae were greatly affected by sex kind of date palm trees. Moreover, the total soluble phenols were significantly increased in female trees as compared to male trees. The maximum increase in total soluble phenols concentration reached 99.24 and $99.00 \%$ respectively over the male trees in the two studied seasons. The data also show that pinnae concentration from total soluble phenols could be used as indicator in early detection of sex in date palm trees.

\section{6- Nitrogen and crude protein \%}

Data recorded in Table (6) show in both seasons that, there is a relationship between pinnae concentration from nitrogen and crude protein and sex expression of date palm trees. The highest concentration from nitrogen and crude protein were obtained with the pinnae of female trees. The increases over the male trees were recorded 49.54and $44.47 \%$ for nitrogen and 49.54 and $44.47 \%$ for crude protein, respectively in the two successive seasons. 
Table (5): Male and female date palm pinnae from silicon and total soluble phenols in 2006 and 2007 seasons.

\begin{tabular}{|c|c|c|c|c|c|c|c|c|}
\hline \multirow{3}{*}{$\begin{array}{c}\text { Trees } \\
\text { No. }\end{array}$} & \multicolumn{4}{|c|}{ Silicon \% } & \multicolumn{4}{|c|}{ Total soluble phenols(mg/g F.W.) } \\
\hline & \multicolumn{2}{|c|}{2006} & \multicolumn{2}{|c|}{2007} & \multicolumn{2}{|c|}{2006} & \multicolumn{2}{|c|}{2007} \\
\hline & Male & Female & Male & Female & Male & Female & Male & Female \\
\hline 1 & 1.39 & 2.51 & 1.45 & 2.66 & 3.87 & 8.36 & 4.36 & 8.20 \\
\hline 2 & 1.46 & 2.45 & 1.51 & 2.61 & 4.15 & 8.10 & 3.71 & 7.90 \\
\hline 3 & 1.48 & 2.54 & 1.51 & 2.71 & 4.10 & 7.85 & 4.19 & 8.15 \\
\hline 4 & 1.45 & 2.66 & 1.48 & 2.56 & 3.85 & 7.73 & 3.60 & 8.12 \\
\hline 5 & 1.46 & 2.46 & 1.52 & 2.53 & 4.15 & 7.79 & 3.70 & 8.35 \\
\hline 6 & 1.52 & 2.45 & 1.43 & 2.71 & 4.20 & 7.21 & 3.90 & 8.10 \\
\hline 7 & 1.53 & 2.55 & 1.41 & 2.51 & 4.15 & 7.90 & 4.26 & 7.50 \\
\hline 8 & 1.51 & 2.71 & 1.49 & 2.49 & 3.58 & 8.12 & 3.91 & 7.71 \\
\hline 9 & 1.49 & 2.55 & 1.47 & 2.36 & 3.68 & 8.18 & 4.20 & 7.60 \\
\hline 10 & 1.55 & 2.45 & 1.46 & 2.39 & 4.16 & 8.10 & 4.31 & 8.21 \\
\hline Mean & 1.48 & 2.53 & 1.47 & 2.55 & 3.98 & 7.93 & 4.01 & 7.98 \\
\hline Sig.5\% & & & & & & * & & \\
\hline
\end{tabular}

Table (6): Male and female date palm pinnae from total nitrogen and crud protein \% in 2006 and 2007 seasons.

\begin{tabular}{|c|c|c|c|c|c|c|c|c|}
\hline \multirow[t]{2}{*}{ Trees } & \multicolumn{4}{|c|}{ Total nitrogen (g/100 g D.W.) } & \multicolumn{4}{|c|}{ Crud protein (g/ 100gD.W.) } \\
\hline & \multicolumn{2}{|c|}{2006} & \multicolumn{2}{|c|}{2007} & \multicolumn{2}{|c|}{2006} & \multicolumn{2}{|c|}{2007} \\
\hline No. & Male & Female & Male & Female & Male & Female & Male & Female \\
\hline 1 & 1.13 & 1.98 & 1.18 & 1.95 & 6.49 & 11.38 & 6.78 & 11.21 \\
\hline 2 & 1.20 & 1.85 & 1.11 & 1.75 & 6.90 & 10.63 & 6.38 & 10.06 \\
\hline 3 & 1.15 & 1.79 & 1.26 & 1.83 & 6.61 & 10.29 & 7.24 & 10.52 \\
\hline 4 & 1.12 & 1.95 & 1.21 & 1.71 & 6.44 & 11.21 & 6.95 & 9.83 \\
\hline 5 & 1.35 & 1.82 & 1.16 & 1.76 & 7.76 & 10.46 & 6.67 & 10.12 \\
\hline 6 & 1.36 & 1.86 & 1.12 & 1.95 & 7.82 & 10.69 & 6.44 & 11.21 \\
\hline 7 & 1.18 & 1.73 & 1.36 & 1.60 & 6.78 & 9.94 & 7.82 & 9.20 \\
\hline 8 & 1.15 & 1.75 & 1.29 & 1.55 & 6.61 & 10.06 & 7.41 & 8.91 \\
\hline 9 & 1.31 & 1.83 & 1.22 & 1.92 & 7.53 & 10.52 & 7.01 & 11.04 \\
\hline $\mathbf{1 0}$ & 1.16 & 1.55 & 1.39 & 1.75 & 6.67 & 8.91 & 7.99 & 10.06 \\
\hline Mean & 1.21 & 1.81 & 1.23 & 1.77 & 6.96 & 10.41 & 7.07 & 10.21 \\
\hline Sig.5\% & & * & & 8 & & & & * \\
\hline
\end{tabular}

\section{7- Total free amino acids concentration:-}

Data in both two seasons presented in Table (7) indicate that, pinnae of female trees contained a high concentration of total free amino acids compared to male trees. Moreover, the total free amino acids were significantly increased in female trees. The maximum increase was 11.53 and $11.68 \%$ respectively over the male trees in the two studied season. These results are in harmony with those obtained by Khan et al. (1982) and Dutta and Mazumdar (1989) in papaya who reported that leaf content of amino acids were higher in pistillate plants as compared with staminate ones.

\section{8- Total indoles concentration:-}

Data recorded in Tables (7) clearly show that, total indoles of pinnae was significantly higher in female trees than the male trees. The increase was

Fayoum J. Agric. Res. \& Dev., Vol.22, No.2, July, 2008 
recorded 17.22 and $13.73 \%$ over the male trees respectively in the two successive seasons. These results are in harmony with those obtained by Salama (1998), in papaya, who pointed out that pistillate plants could be predicted through the higher leaf blade and petiole content of total indoles.

Table (7): Male and female date palm pinnae concentration from total free amino acids and total indoles in 2006 and 2007 seasons .

\begin{tabular}{|c|c|c|c|c|c|c|c|c|}
\hline \multirow{3}{*}{$\begin{array}{l}\text { Trees } \\
\text { No. }\end{array}$} & \multicolumn{4}{|c|}{ Total free amino acids (mg/g D.W.) } & \multicolumn{4}{|c|}{ Total indoles (mg/ g F.W.) } \\
\hline & \multicolumn{2}{|c|}{2006} & \multicolumn{2}{|c|}{2007} & \multicolumn{2}{|c|}{2006} & \multicolumn{2}{|c|}{2007} \\
\hline & Male & Female & Male & Female & Male & Female & Male & Female \\
\hline 1 & 12.03 & 13.06 & 11.22 & 12.61 & 0.86 & 1.65 & 0.83 & 1.73 \\
\hline 2 & 12.01 & 13.20 & 11.60 & 13.31 & 0.83 & 1.56 & 0.91 & 1.74 \\
\hline 3 & 11.81 & 12.70 & 12.05 & 13.01 & 0.78 & 1.73 & 0.92 & 1.63 \\
\hline 4 & 11.73 & 12.89 & 11.90 & 13.21 & 0.90 & 1.50 & 0.75 & 1.66 \\
\hline 5 & 11.65 & 12.55 & 12.01 & 13.15 & 0.96 & 1.45 & 0.78 & 1.65 \\
\hline 6 & 11.80 & 13.17 & 11.71 & 12.91 & 0.90 & 1.48 & 0.85 & 1.61 \\
\hline 7 & 11.10 & 12.98 & 11.26 & 12.40 & 0.80 & 1.56 & 0.93 & 1.71 \\
\hline 8 & 11.21 & 13.31 & 11.61 & 13.05 & 0.78 & 1.71 & 0.90 & 1.60 \\
\hline 9 & 11.65 & 13.12 & 11.30 & 13.31 & 0.86 & 1.55 & 0.75 & 1.45 \\
\hline 10 & 11.21 & 12.70 & 11.73 & 13.05 & 0.80 & 1.60 & 0.91 & 1.66 \\
\hline Mean & 11.62 & 12.96 & 11.64 & 13.00 & 0.84 & 1.57 & 0.85 & 1.64 \\
\hline Sig.5\% & & k & & * & & & & * \\
\hline
\end{tabular}

\section{9- Free proline concentration:}

The data in Table (8) reveal that, pinnae of staminate trees showed higher concentration of free proline in comparison with the corresponding ones of pistillate trees in the first and second seasons,. The increase was recorded 17.22 and $13.73 \%$ over the female trees in the two studied seasons respectively. In this concern, pinnae content of free proline could be used as indicator in early detection of sex in date palm trees. These results are in contrast with that obtained by Salama (1998), in papaya, who pointed out that pistillate plants could be predicted through the higher leaf blade of free proline. On the other hand we can simply differentiate between the male and female date palm by the colour of toluene extraction of pinnae sample which had orange colour for female date palm trees and red colour for male date palm trees.

\section{0- Ash concentration:}

Table (8) indicate in both seasons that, there is a relationship between pinnae $\%$ of ash and sex expression of date palm trees. In other words, pinnae of male trees recoded higher values of ash in comparison with female trees. The increase was recorded 14.78 and $13.81 \%$ over the female trees in the first and second seasons, respectively. These results are in harmony with those obtained by Helail and Atawia (1990) in papaya, who stated that leaf ash content of male plants was higher than those of female ones. 
Table (8): Male and female date palm pinnae from free proline and ash in 2006 and 2007 seasons.

\begin{tabular}{|c|c|c|c|c|c|c|c|c|}
\hline \multirow{3}{*}{$\begin{array}{c}\text { Trees } \\
\text { No. }\end{array}$} & \multicolumn{4}{|c|}{ Free proline (mg/ g D.W.) } & \multicolumn{4}{|c|}{ Ash \% } \\
\hline & \multicolumn{2}{|c|}{2006} & \multicolumn{2}{|c|}{2007} & \multicolumn{2}{|c|}{2006} & \multicolumn{2}{|c|}{2007} \\
\hline & Male & Female & Male & Female & Male & Female & Male & Female \\
\hline 1 & 9.18 & 8.10 & 8.65 & 8.01 & 8.10 & 7.48 & 8.01 & 7.53 \\
\hline 2 & 9.22 & 8.05 & 8.95 & 7.60 & 8.05 & 7.30 & 7.60 & 7.65 \\
\hline 3 & 8.91 & 7.21 & 8.76 & 8.01 & 7.21 & 7.61 & 8.01 & 7.41 \\
\hline 4 & 9.10 & 7.55 & 9.25 & 7.91 & 7.55 & 7.20 & 7.91 & 7.55 \\
\hline 5 & 9.31 & 7.16 & 8.90 & 7.95 & 7.16 & 7.63 & 7.95 & 7.41 \\
\hline 6 & 8.80 & 8.12 & 9.21 & 7.60 & 8.12 & 7.55 & 7.60 & 7.66 \\
\hline 7 & 9.11 & 8.21 & 9.16 & 7.85 & 8.21 & 7.36 & 7.85 & 7.29 \\
\hline 8 & 9.25 & 7.17 & 9.08 & 7.26 & 7.17 & 7.56 & 7.26 & 7.65 \\
\hline 9 & 8.66 & 7.68 & 8.90 & 7.86 & 7.68 & 7.46 & 7.86 & 7.69 \\
\hline 10 & 8.98 & 8.01 & 7.83 & 7.88 & 8.01 & 7.29 & 7.88 & 7.53 \\
\hline Mean & 9.05 & 7.72 & 8.86 & 7.79 & 7.72 & 7.44 & 7.79 & 7.53 \\
\hline Sig.5\% & & & & & & S. & & \\
\hline
\end{tabular}

\section{DISCUSSION}

It is clear from the present data that, female date palm trees were characterized by high activity in the anabolic processes as compared to male once, which leads to the accumulation of very important substances that serves in plant metabolism and in predicting sex of date palm (male or female). In this connection, the increase in chlorophyll a \& b as well as total caroteniods in pinnae of female trees may be due to the increase in nitrogen concentration (Table 6) which play an important role in stimulating chlorophyll synthesis enzymes which reflected on formation of chlorophyll molecule. Moreover, the increase in total anthocyanin in pinnae of female trees may be attributed to the increase in the concentration of sugars in pinnae trees (Table 3). In this respect, El-Yazal and Abd El- Samie (2002) reported that the increase in anthocyanin may be attributed to the increase in the concentration of sugars in plants. The increase in total sugars and carbohydrates concentrations in pinnae female date palm may be directly or indirectly attributed to the effect of certain enzymes that may activate the anabolic processes leading to the accumulation of these substances. Also, the increase in dry matter in pinnae of female trees could be attributed to the stimulating effect of enzymes on chlorophyll formation (Table1) and consequently photosynthesis which reflected on vegetative growth and physiological processes, i.e. increasing number of cells through cell division and meristematic activity of tissues. The increase in total soluble phenols concentration in pinnae of female trees may be attributed to the increase in metabolic activity in these trees to synthesize shikimic acid. The increase in nitrogen in pinnae of female trees may be attributed to the increase in the concentration of auxin (IAA) (Table 7) which promote rooting process and consequently the amounts of mineral elements absorbed and translocated into the different parts of the trees. The increase in total indoles in pinnae of female trees may be attributed to the increase in the concentration of total free amino acids (Table 7) especially the synthesis of tryptophan amino acid and consequently in the formation of natural auxin in trees i.e. indole-3- acetic

Fayoum J. Agric. Res. \& Dev., Vol.22, No.2, July, 2008 
acid (IAA). In this connection, Salama (1998), using papaya, pointed out that pistillate plants could be predicted through the higher leaf blade and petiole content from, total indoles.

Finally, from the present results, it could be concluded that ,female date palm trees could be predicted through the higher pinnae content from chlorophyll a \& b, total caroteniods, anthocyanin, total carbohydrates, total sugars, reducing sugars, dry matter, silicon, total free amino acids and total indoles,. On the other hand, early detection of male trees could be forecasted through higher pinnae content from ash and proline.

\section{REFERENCES}

Abd El-Rawy, H. (2001). Effect of different source of pollen on yield and fruit quality in some date palm cultivars. M. Sc. Thesis, Fac. Agric. Assiut Univ., pp. 38-89.

A.O.A.C. (1995). Official Methods of Analysis of the Association of Official Agricultural Chemists. Sixteenth ed., Washington D.C., USA.

Ashour, N.E.; Hassan, H.S.A. and Mostafa, E.A.M. (2004). Yield and fruit quality of zaghloul and samani date palm (Phoenix dactylifera, L.) as affected by pollination methods .Annals Agric. Sci., Ain Shams Univ., Cairo, 49 (2) 631-642.

Bahgat, M. and Brown, T.W. (1958). Dates of Egypt. Bull. 24, Hort. Dept. Ministry of Agric., A.R.E.

Bates, L.S.; Waldren, R.P. and Tearc, I.D. (1973). Rapid determination of free proline for water stress studies. Plant and Soil, 39: 205-207.

Dutta, P.K. and Mazumdar, B.C. (1989). Studies on the protein content of male and female papaya (Carica papaya L.) trees. South India Horticulture, 37: 590-595.

El-Ghayaty, S.H. (1982). Effects of different pollinators on fruit setting and some fruit properties of "Seewy and Amhat" date varieties. Proc of $1^{\text {st }}$ symposium on date palm. King Faisal Univ., Al- Hassa, Saudi Arabia, pp. 72-82.

El- Makhtoun, F.M.B. (1979). Effect of different pollen type on fruiting and quality in some date varieties. M. Sc. Thesis, Fac. of Agric., AlAzhar Univ., Cairo.

El-Yazal, M.A. and Abd El-Samie, F.S. (2002). Phyiological studies on the effect of weed control treatments on growth,yield and some chemical constituents of broad bean (Vicia faba L.) plants.Annals of Agric.Sci.Moshtohor,40:199-221.

Fuleki, I. and Francis, F.J. (1968). Quantitative methods for anthocyanins. 1Extraction and determination of total anthocyanin in Garnberries. J. of Food. Sci., 33: 72-77.

Hafez, A. and Mikkelsen, D.S. (1981). Colorimetric determination of nitrogen for evaluating the nutritional status of rice. Commnu. Soil Sci. and Plant Analysis, 12 (1): 61-69.

Hanna, J.W. (1964). Method for chemical analysis of soil. In : Chemistry of the soil. Firman E. Bezn, $2^{\text {nd }}$ Oxford, IBB Pubishing Co. New Delhi Bombay Callcuta, pp. 474-480.

Helail, B.M. and Atawia, A.A.R. (1990). Sex expression of papaya plants in relation to some leaf chemical constituents. Egypt. J. Appl. Sci., 5 (2): $130-137$. 
Higazy, M.K.; El-Ghayaty, S.H. and El-Makhtoun, F.B. (1982a). Effect of pollen type on fruits setting, yield and some physical fruit properties of some date palms. Proc. $1^{\text {st }}$ symposium on date palm. King Faisal Univ., Al-Hassa, Saudi Arabia, 1: 84-93.

Higazy, M.K.; El-Ghayaty, S.H. and El- Makhtoun, F.B. (1982b). Effect of different pollen types on fruit chemical properties of some date varieties. Proc. $1^{\text {st }}$ symposium on date palm. King Faisal Univ., AlHassa, Saudi Arabia, 1: 94-101.

Jayarman, J. (1981). Laboratory Manual in Biochemistry. Wiley Eastern Limited New York, pp. 61-73.

Khalifa, A.S.; Hamdy, Z. M.; Azzouz, S.; El-Masery, H. and Yousef, M. (1980). Effect of sources of pollen on the physical and chemical quality of "Amhat date variety. Hort. Res. Inst., Agric. Res. Cent., Ministry of Agric. Res. Rev., 58 (3): 15-23.

Khan, M.A.A.; Rahman, M.A.; Uddin, M.N. and Hossain, M.Z. (1982). Observation on amino acid contents in male and female papaya lants. Bangladesh Horticulture, 10(2): 24-29. [En, 6 ref] Chittagong Univ., Chittagong Bangladesh.

Larson, P.; Harbo, A.; Klunsour, S. and Aasheim, T. (1962). On the biogenesis of some indole compounds in Acetobacter xylimum. Physiology Plantarum, (15): 552-565.

Michel, K.A.; Gilles, J.K.; Hamiltion, P.A. and Freed, S. (1956). Colorimetric method for determination of sugars and related substances. Analytical chemistry, 28(3): 121-126.

Mohammed, M.A.E. (2004). Evaluation and selection of some seedling date palm males and their effects on fruiting and fruit quality of "Seewy" date palms. M.Sc. Thesis, Fac. Agric. Fayoum, Cairo, Univ.

Moustafa, A.A. (2001). The effect of pollen source on fruit characteristics of "Seewy" date cultivar. Abstracts of the second international conference on date palms. United Arab Emirates Univ., Al- Ain, United Arab Emirates, pp.4.

Salama, A.S.M. (1998). Studies on growth and flowering of papaya. M.Sc. Thesis, Fac. Agric. Moshtohor, Zagazig Univ.

Snedecor, G.W. and Cochran, W.G. (1980). Statistical Methods. $7^{\text {th }}$ Ed., Iowa State Univ. press, Ames, Iowa, USA.

Welburn, A.R. and Lichtenthaler, H. (1984). Formula and program to determine total caroteniods and chlorophyll $\mathrm{a}$ and $\mathrm{b}$ of leaf extracts in different solvents. In Advances in Photosynthesis Research (Sybesma C.Ed.), II : 9- 12.

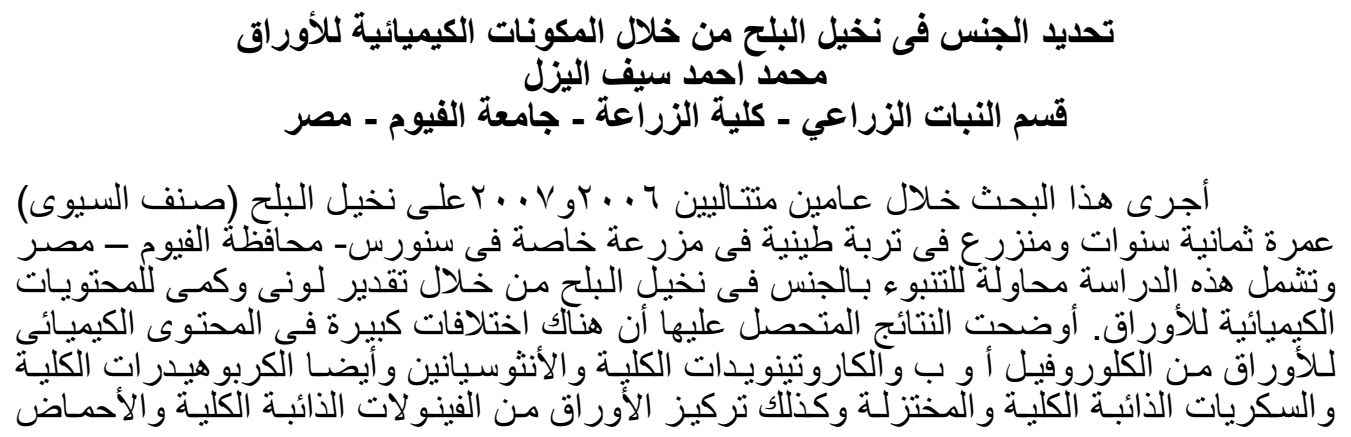

Fayoum J. Agric. Res. \& Dev., Vol.22, No.2, July, 2008 


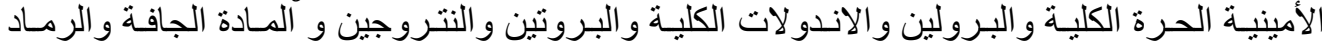

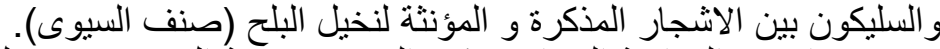

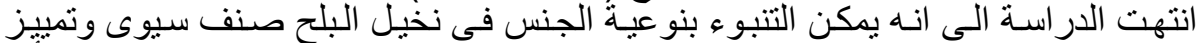

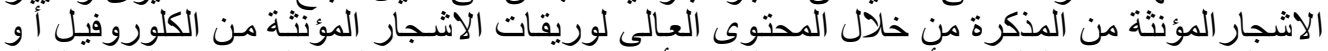

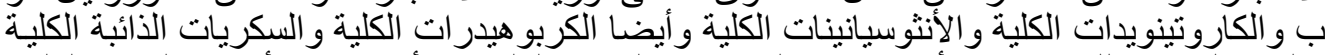

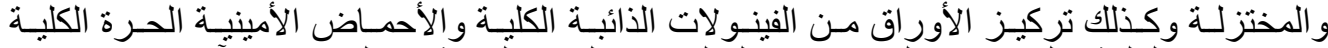

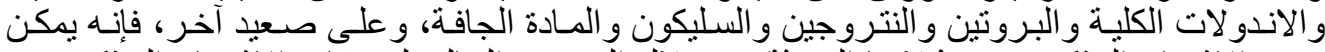

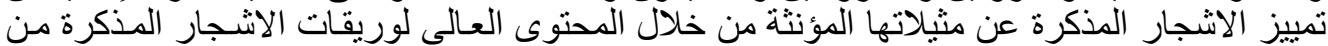

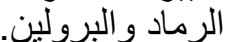

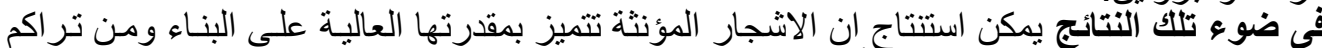

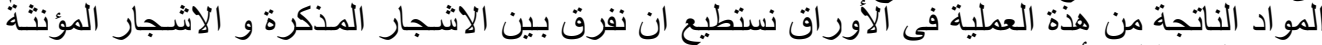

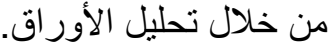

